\title{
Exon 10 prolactin receptor gene polymorphism in Surti and Jaffarabadi buffaloes
}

\author{
Savita Devkatte ${ }^{1}$, Mamta Janmeda ${ }^{1}$, Santul Patel ${ }^{1}$, TKS Rao ${ }^{2}$ and Vishnu Kharadi ${ }^{1}$
}

Received: 19 July 2021 / Accepted: 30 August 2021 / Published online: 21 December 2021

(C) Indian Dairy Association (India) 2021

\begin{abstract}
The present study was undertaken with the objectives to amplify Prolactin Receptor (PRLR) gene exon 10 region and to study PRLR gene polymorphism using PCR-RFLP in Surti and Jaffarabadi buffaloes. Blood samples from 50 Surti and Jaffarabadi buffaloes each were collected followed by DNA was extracted by phenol: chloroform method. Oligo primers specific to bovine PRLR loci were custom synthesized at Eurofins and utilized in the present experiment. Exon 10 region of PRLR gene resulted in $168 \mathrm{bp}$ product. Restriction digestion of $168 \mathrm{bp}$ fragment of PRLR gene using SmlI, revealed PCR products with a single band of GG genotype. The frequency of genotype GG and gene $\mathrm{G}$ were observed 1.0 each for both Surti and Jaffarabadi buffalo respectively. Both the population of buffaloes were found to be in genetic equilibrium for PRLR gene of exon 10 locus indicating that monomorphism at these loci may be a species characteristic of buffalo.
\end{abstract}

Keywords: Buffalo, Prolactin receptor, Polymorphism, PCRRFLP

India with rich domestic animal genetic resources and which are associated with the social, cultural and traditional values of the region to which they belong and serve as vital source for food, draught power, manure and provide much needed selfemployment to small and marginal farmers (Anonymous 2020). In India buffaloes are preferred over cattle as a dairy animal and are called "The black gold of India" because of high milk fat content which fetches higher market price.

${ }^{1}$ Department of Animal Genetics and Breeding, College of Veterinary Sciences, Navsari Agricultural University, Navsari, India

${ }^{2}$ Department of LPM, College of Veterinary Sciences, Navsari Agricultural University, Navsari, India

Mamta Janmeda $(\square)$

Department of Animal Genetics and Breeding, College of Veterinary Sciences, Navsari Agricultural University, Navsari, India

E-mail: janmedamamta14@gmail.com
Development in DNA technologies have made it possible to uncover a large number of genetic polymorphisms at the DNA sequence level and to use them as markers for evaluation of the genetic basis for observed phenotypic variability which makes a vital part in animal breeding (Athe et al. 2018). Many candidate genes with putative effects on economically important traits have been investigated in many cattle and buffalo breeds, some were reported to affect milk production traits e.g. PRLR, PRL, LEPR, DGAT1 etc. Prolactin (PRL) and Prolactin Receptor (PRLR) are peptide hormones secreted from the anterior pituitary gland and play an important regulatory function in mammary gland development, maintenance of milk secretion and reproduction.

Several polymorphic sites have been detected in different buffalo breeds and reported Single Nucleotide Polymorphisms (SNPs) in PRLR gene including Murrah and Mehsana (Javed et al. 2011a; Javed et al. 2011b), Murrah and Nili-Ravi and crossbred buffaloes (Abakar et al. 2018), Italian Mediterranean River buffaloes (Cosenza et al. 2018) and Egyptian Buffaloes (El-Magd et al. 2021).

The Surti and Jaffarabadi are two divergent buffalo breeds of Gujarat having star performance status as the premier dairy animal of the India. However, there is no report available in Surti and Jaffarabadi buffalo breeds of PRLR gene polymorphism and its effects on milk production traits. The present study was undertaken with the objectives to amplify PRLR gene exon 10 region and to study PRLR gene polymorphism using Polymerase Chain Reaction-restriction Fragment Length Polymorphism (PCRRFLP) in Surti and Jaffarabadi buffaloes.

Surti buffaloes, maintained at Livestock Research Station under Navsari Agricultural University, Navsari and Jaffarabadi buffaloes, maintained at Patel Dairy Farm, Navsari, were used in present research work. About $5 \mathrm{ml}$ of the blood was collected from each animal from the jugular vein and genomic DNA was isolated from blood samples using standard phenol-chloroform extraction method by John et al. (1991). The concentration and purity of genomic DNA was determined spectrophotometrically at $\mathrm{OD}_{260}$ and $\mathrm{OD}_{280}$.

Oligo primers specific to bovine PRLR loci utilized in the present study (F- 5'AGATGGAGTGCTGGCTCTGT3' and R- 
Table 1 Gene and genotypic frequencies of PRLR gene

\begin{tabular}{|c|c|c|c|c|c|c|c|c|c|c|c|}
\hline \multirow[t]{2}{*}{$\begin{array}{l}\text { Breed } \\
(\mathrm{n}=50)\end{array}$} & \multicolumn{3}{|c|}{$\begin{array}{l}\text { Observed no. } \\
\text { of genotype }\end{array}$} & \multicolumn{3}{|c|}{$\begin{array}{l}\text { Genotypic } \\
\text { Frequency }\end{array}$} & \multicolumn{2}{|c|}{$\begin{array}{l}\text { Gene } \\
\text { Frequency }\end{array}$} & \multicolumn{3}{|c|}{$\begin{array}{l}\text { Expected no. } \\
\text { of genotype }\end{array}$} \\
\hline & $\overline{\mathrm{GG}}$ & GT & TT & GG & GT & TT & $\mathrm{G}$ & $\mathrm{T}$ & GG & GT & TT \\
\hline Surti & 50 & 00 & 00 & 1.00 & 0.00 & 0.00 & 1.0 & 0.0 & 50 & 00 & 00 \\
\hline Jaffarabadi & 50 & 00 & 00 & 1.00 & 0.00 & 0.00 & 1.0 & 0.0 & 50 & 00 & 00 \\
\hline
\end{tabular}

5'GCCTTCTTGGCTGGTTCTTC3') as per Parihar et al.(2017)were custom synthesized by Eurofins Genomics. PCR reaction was carried out in total volume of $25 \mu \mathrm{l}$ that included $12.5 \mu \mathrm{l}$ of $2 \mathrm{X}$ master mix (by Takara Ltd.), $3 \mu$ of genomic DNA $(90 \mathrm{ng}), 1 \mu \mathrm{l}$ of each forward and reverse primer $(10$ pmole $)$ and $7.5 \mu 1$ of nuclease free water with annealing temperature of $60^{\circ} \mathrm{C}$.

Restriction fragment digestion of amplified products (168 bp) were carried with SmlI (Thermo Scientific Biolab) out in a total reaction volume of $21 \mu \mathrm{l}$ at incubation of $30^{\circ} \mathrm{C}$ for $16 \mathrm{hrs}$ followed by inactivation of $65^{\circ} \mathrm{C}$ for $20 \mathrm{~min}$. Digested products were checked on $2.0 \%$ agarose gel in $0.5 \mathrm{X} \mathrm{TBE}$ buffer for 60 to 90 minutes at 5 $\mathrm{V} / \mathrm{cm}$. The band size were judged by comparing with $50 \mathrm{bp}$ DNA ladder and recorded. Genotyping of PRLR loci were carried out according to the band pattern of respective genotypes.

The amplified fragments of the PRLR gene exon 10 region revealed about 168 bp PCR product in both Surti and Jaffrabadi buffaloe breeds. As per Deepika et al. (2014), SmlI restriction analysis of the PCR product yields three different genotypes viz., GG genotype (168 bp), GT genotype (168, 123 and $45 \mathrm{bps})$ and TT genotype (123 and 45 bps).

In present study on restriction digestion of exon 10 region of PRLR gene using SmlI revealed RFLP pattern with only one genotype (GG) and one allele $(\mathrm{G})$ for the locus in both Surti and Jaffarabadi buffaloes as presented in table 1. Screened buffalo population used in present study was found monomorphic in nature.

In contrast to the present study, Javed et al. (2011a; 2011b) reported six buffalo- specific SNPs in PRLR gene in B. bubalis . Abakar et al. (2018) detected a SNP at 9637 (T/C) in exons 10 of PRLR gene in Murrah, Nili-Ravi, and crossbred buffaloes. Cosenza et al. (2018) sequenced and detected the SNP in exon 10 in 308 Italian Mediterranean river buffaloes. El-Magd et al. (2021) detected two SNPs in exon 10 of PRLR gene in Egyptian Buffaloes.

Associations between PRLR variants and milk production traits have been reported by various authors. Abakar et al. (2018) reported association in PRLR exon 10 in Murrah buffaloes with milk yield, with a significant difference between the TT and CC genotypes. Xinfeng et al. (2020) reported that individuals with genotype DD showed better phenotypic traits than individuals with other genotypes at the two loci of PRLR gene in Shaanbei white cashmere goats. El-Magd et al. (2021) reported Egyptian buffaloes with GT haplotypes showed significantly higher milk yield, fat $\%$ and protein $\%$, mRNA and protein levels PRLR in milk somatic cells than AC, AT and GC haplotypes.

\section{Conclusion}

PRLR 168 bp region (exon 10) amplified with bovine specific primers showed monomorphic restriction pattern on digestion with SmlI enzyme in Surti and Jaffarabadi buffaloes. Genotypic $(\mathrm{GG})$ and gene $(\mathrm{G})$ frequencies were recorded as 1.0 each in Surti and Jaffarabadi buffaloes respectively. It could be inferred that further study is required to validate PRLR gene to be used as molecular marker in selection to improve the milk production performance in Buffaloes.

\section{References}

Abakar A, Yang J, Guang S, Bin P, Bao J, Sheng J (2018) Associations between prolactin receptor (PRLR) polymorphisms and milk production traits in dairy buffalo. Can J Anim Sci 50:2-22

Anonymous (2020). Available on www.vikaspedia.in/agriculture/livestock. Accessed on 12 September 2020

Athe R, Naha B, Neerasa GC, Parthasarathi BC, Nukala R, Devara D (2018) Molecular Markers-Characteristics and Applications in Animal Breeding. Int J Livest Res 8: 1-7

Cosenza G, Iannaccone M, Auzino B, Macciotta N P, Kovitvadhi A, Nicolae I, Pauciullo A (2018) Remarkable genetic diversity detected at river buffalo prolactin receptor (PRLR) gene and association studies with milk fatty acid composition. J Anim Genet 10: 11-11

Deepika, Salar RK (2014) Polymorphism studies of Prolactin Receptor (PRLR) gene in Indigenous Grey Cattle breeds of India. Int J Biomed Life Sci 51: 2278-8301

El-Magd MA, Fath, A, Kahilo KA, Saleh AA, El Sheikh AI, AL-Shami S, El-Komy SM (2021) Polymorphisms of the PRLR Gene and their association with milk production traits in egyptian buffaloes. Animals 11: $1237-1247$

Javed R, Gautam SK, Vijh RK, Tantia MS (2011a) Six novel PCR-RFLP loci in milk quality candidate genes in Bubalus bubalis. Int J Livest Prod 2: 79-83

Javed R, Gautam SK, Vijh RK, Tantia MS (2011b) Characterization of PRLR and PPARGC1A genes in buffalo (Bubalus bubalis). Genet Mol Biol 34:592-594

John SW, Weitzner G, Rozen R, Seriver CR (1991) A rapid procedure for extracting genomic DNA from leukocytes. Nucleic Acids Res 19: 408-409

Parihar G, Sharma D, Singh SP, Tiwari M, Goel R, Singh, Pandey V (2017) Genetic Polymorphism Study in Prolactin Receptor (PRLR) Gene and their Association with Milk Production Traits in Indian Cattle Breeds. J Anim Res 7:673-677.

Xinfeng L, Lin M, Min W, Ke W, Jie L, Hailong Y, Haijing Z, Xianyong L (2020) Two indel variants of Prolactin Receptor (PRLR) gene are associated with growth traits in goat. Anim Biotechnol 31: 314323 